\title{
LÆVOCARDIA WITH TRANSPOSITION OF THE ABDOMINAL VISCERA
}

\author{
BY \\ MAURICE CAMPBELL \\ From the Cardiac Department, Guy's Hospital
}

Lævocardia with transposition of the abdominal viscera is uncommon, and Fitzgerald's (1960) report of such a case with a necropsy has stimulated me to report another. Both cases belong to the less common group where the $\mathbf{P}$ wave in lead $I$ is inverted and the venous atrium and the venæ cavæ are on the left side. This means that the venæ cavæ at least are transposed in the same way as the abdominal viscera, but not necessarily the atria, for the atrium on the left may be a real left atrium functioning as a venous atrium rather than a transposed right atrium.

Our patient was 14 years old when he was investigated, and later he was reported as Case 3 by Campbell and Forgacs (1953). He got on well till he was 20 when he developed subacute bacterial endocarditis. He was cured of this infection, but died the following year in 1957 with congestive heart failure.

For the result of the investigations, we quote from our earlier paper with some omissions. "Cardiac catheterization from the left arm proved that the superior and inferior venæ cavæ were on the left and drained into the left atrium. From here, the catheter entered a venous left ventricle. It passed also, through a large atrial septal defect, into the right atrium, which received one and probably all of the pulmonary veins, and from the right atrium into the right ventricle, in both of which the oxygen saturation was higher (78$80 \%$ ) than on the left side of the heart $(66-68 \%)$. Neither aorta nor pulmonary trunk could be entered, but the oxygen saturation of 78 per cent in the aorta showed that it came mainly from the right ventricle, which had the same systolic pressure as the systemic arteries. Angiocardiography confirmed that the venous atrium was on the left and that there was a large veno-arterial shunt from left to right, so that the heart seemed generally filled at 3 seconds. The aorta, situated well to the right and with a right-sided arch, became opaque at 4 seconds. The pulmonary trunk was not seen but the pulmonary arteries became opaque between 2 and 4 seconds."

All these findings were substantially confirmed by the necropsy and extended by three additional points. (1) We thought that the aorta arose "mainly from the right ventricle": in fact it arose entirely from this chamber. (2) We did not know where the pulmonary trunk originated: it arose from the left ventricle. (3) We thought he had pulmonary stenosis, because the systolic pressure in the venous (left) ventricle was higher than that in the arterial (right) ventricle $(128$ against $107 \mathrm{~mm}$. $\mathrm{Hg}$ ) and there was a large left-to-right (veno-arterial) shunt, though it seemed to be mainly at atrial level. In fact, he had a double stenosis, both at the pulmonary valve and $1 \mathrm{~cm}$. lower in the infundibulum.

At necropsy, the heart weighed $470 \mathrm{~g}$. It was rather centrally placed with the apex pointing to the left, and the abdominal viscera were transposed. The superior and inferior venæ cavæ were both on the left side, and entered the left (venous) atrium, which measured about 4 by $4.5 \mathrm{~cm}$. This communicated with a larger right (arterial) atrium, about 6 by $6 \mathrm{~cm}$., through a large atrial septal defect, measuring 2.2 by $1.2 \mathrm{~cm}$. It also communicated with a small posterior left ventricle, about 2 by $5.5 \mathrm{~cm}$., through a valve that was tricuspid, though one cusp was much smaller than the other two.

Posterior and to the left of the attachment of this valve there was a small obstructed outflow tract leading to the stenosed pulmonary valve. Below and to the right was a ventricular septal defect; this was at the usual site and measured 1.4 by $0.6 \mathrm{~cm}$. The outflow tract was obstructed by a firm ridge that did not encircle the whole tract, and was further obstructed by vegetations: there was no encircling diaphragm as in many cases of infundibular stenosis. Above this there was a wide saccu- 
lated chamber, about $1 \mathrm{~cm}$. long, ending in a second obstruction at the valve. The pulmonary ring was small and partly calcified, and the opening was only $5 \mathrm{~mm}$. in diameter. The valve was of the usual dome shape and was made up probably of three cusps, though we could not be certain about this: it was ringed by vegetations and further obstructed by clot. Above this the pulmonary trunk divided into quite wide left and right pulmonary arteries.

The pulmonary veins entered the larger right (arterial) atrium, which led through a bicuspid valve to the large anterior right ventricle. This occupied nearly all the anterior aspect of the heart and measured about 6.5 by $8.5 \mathrm{~cm}$. The aorta arose from this large right ventricle and the valve had three cusps. The aorta was smaller than normally, arched to the right, and pierced the diaphragm behind and to the right of the inferior vena cava.

The mitral, tricuspid, and pulmonary valves all had firm verrucose vegetations suggesting that the infection had been cured.

The liver (on the left) was congested and weighed $2580 \mathrm{~g}$. The spleen (on the right) was firm and congested and weighed $500 \mathrm{~g}$. No other congenital malformation was found.

\section{Discussion}

It is satisfactory that even in such complex cases, modern investigations can establish several of the main abnormalities, though nothing but a necropsy can be decisive and fill in all the details. Campbell and Forgacs (1953) concluded that the malformations in isolated lævocardia were nearly. always multiple, atrial and ventricular septal defects, pulmonary stenosis or atresia, and transposition of the main vessels all being common in various combinations.

This case and the one reported by Fitzgerald (1960) add two more to the small number of cases with necropsies. Both had ventricular septal defects and pulmonary stenosis: ours had also a large atrial septal defect, but Fitzgerald's had not. As in several cases, the cyanosis and functional defects are caused by these added malformations, for without them the circulation in our patient should have functioned normally and he should have been acyanotic, the systemic venous blood passing to the pulmonary arteries and the blood from the lungs passing to the aorta as normally.

Fitzgerald (1960) suggests that the main differences are in the arrangement of the aorta and pulmonary trunk from the ventricles. Our case resembles that of Muscovitz et al. (1952) which he quotes, since the aorta arose from the right ventricle and the pulmonary trunk from the left ventricle.

I should like to thank Dr. Danino for the clinical account of his last illness and Dr. Mary Sharp for her account of the necropsy and for sending me the heart to examine.

\section{References}

Campbell, M., and Forgacs, P. (1953). Brit. Heart J., 15, 401.

Fitzgerald, M. J. T. (1960). Brit. Heart J., 22, 429.

Muscovitz, H. L., Gordon, A. J., and Scherlis, L. (1952). Amer. Heart J., 44, 184. 